JRPB, Vol. 7, No. 2, September 2019, Hal. 256-263

DOI: $10.29303 /$ jrpb.v7i2.145

ISSN 2301-8119, e-ISSN 2443-1354

Tersedia online di http://jrpb.unram.ac.id/

\title{
EFEK TEGANGAN SEARAH (DC) TERHADAP DEWATERING PASTA TOMAT MENGGUNAKAN METODE ELECTROOSMOSIS DEWATERING
}

\author{
Effect of DC Voltage on Tomato Paste Dewatering \\ using Electroosmosis Dewatering Method \\ Joko Prasetyo $^{1, *)}$, Kamsiatun Eka Pratama ${ }^{1}$, Anang Lastriyanto ${ }^{1}$ \\ ${ }^{1}$ Jurusan Keteknikan Pertanian, Fakultas Teknologi Pertanian, Universitas Brawijaya \\ Jl.Veteran, Malang 65145 \\ Email ${ }^{*)}$ : joko.prasetyo@ub.ac.id
}

Diterima: Juli 2019

Disetujui: September 2019

\begin{abstract}
Tomato paste production is conducted by evaporation process to remove some of the water content. However, giving heat to evaporation can damage nutritional content of the paste. Electroosmosis dewatering is method for reducing water content by placing colloidal suspensions between two electrodes. This method is an interesting method to concentrate the suspension that is sensitive to heat. Based on this, research is needed to determine the effect of electroosmosis on reducing water content in tomato paste. In this study, the DC Voltage variations used were $0 \mathrm{~V} ; 4.5 \mathrm{~V} ; 9 \mathrm{~V} ; 18 \mathrm{~V}$ and $36 \mathrm{~V}$ with 100 minutes processing time. The parameters measured based on these variations were changes in DC current during the EOD process and water content of tomato paste. The results showed that DC electric current decreased with increasing processing time, and increased with the increasing voltage. The electric current at the lowest voltage variation (4.5 VDC) is $41.40 \mathrm{~mA}-59.7 \mathrm{~mA}$, while the electric current at the highest voltage variation (36 VDC) reaches $231.86 \mathrm{~mA}-776.67 \mathrm{~mA}$. The increasing DC voltage, the tomato paste water content decreases, therefore the best stress for the dewatering process is $36 \mathrm{~V}$.
\end{abstract}

Keywords: electroosmosis dewatering, tomato paste, DC voltage

\begin{abstract}
ABSTRAK
Secara umum proses pembuatan pasta tomat dilakukan dengan proses evaporasi untuk menghilangkan sebagian kadar air. Namun pemberian panas pada evaporasi dapat merusak kandungan nutrisi pasta. Electroosmosis dewatering (EOD) merupakan metode dalam pengurangan kadar air dengan menempatkan suspensi koloid diantara dua elektroda. Metode ini menjadi hal yang menarik untuk memekatkan suspensi pasta buah yang peka terhadap panas. Berdasarkan hal tersebut, diperlukan penelitian untuk mengetahui pengaruh elektroosmosis terhadap pengurangan kadar air pada pasta buah
\end{abstract}


tomat. Dalam penelitian ini variasi tegangan DC yang digunakan adalah $0 \mathrm{~V} ; 4,5 \mathrm{~V} ; 9 \mathrm{~V}$; $18 \mathrm{~V}$ dan $36 \mathrm{~V}$ dengan waktu proses 100 menit. Parameter yang diukur berdasarkan variasi tersebut adalah perubahan arus DC selama proses EOD dan kadar air pasta tomat. Hasil penelitian menunjukkan bahwa arus listrik DC semakin rendah dengan semakin lama waktu proses, dan semakin meningkat dengan adanya peningkatan tegangan yang diberikan. Aliran arus listrik pada variasi tegangan terendah, yaitu 4,5 V DC adalah di antara 41,40 mA - 59,7 mA, sedangkan arus listrik pada variasi tegangan tertinggi yaitu 36 V DC mencapai 231,86 mA - 776,67 mA. Semakin meningkatnya tegangan DC, maka kadar air pasta tomat semakin berkurang, sehingga tegangan terbaik untuk proses dewatering adalah $36 \mathrm{~V}$.

Kata kunci: electroosmosis dewatering, pasta tomat, tegangan DC

\section{PENDAHULUAN}

\section{Latar Belakang}

Tomat (Solanum lycopersicum) termasuk komoditas hortikultura yang banyak tersebar di Indonesia. Pada tahun 2017 produksi tomat di Indonesia meningkat sebesar $9,01 \%$ dibandingkan tahun 2016 dengan total produksi 962,849 ton (Suhariyanto, 2018). Tingginya tingkat produksi membuat tomat termasuk buah yang populer dan banyak dikonsumsi masyarakat. Menurut data Badan Pusat Statistik, pada tahun 2016 konsumsi tomat oleh masyarakat mencapai mencapai 4,46 kg per kapita per tahun (BPS, 2017). Selain popular, buah ini juga mengandung sejumlah nutrisi penting untuk tubuh seperti, karbohidrat, vitamin C, vitamin A, vitamin B1, vitamin B2, likopen, zat besi, serat, mineral, dan lain sebagainya. Di sisi lain, tomat termasuk buah klimaterik, dimana proses pematangan masih dapat terjadi setelah buah dipanen dari pohonnya, sehingga buah ini akan membusuk jika tidak segera dikonsumsi. Berdasarkan kondisi tersebut perlu dilakukan pengolahan buah tomat menjadi produk potensial, salah satunya yaitu pasta tomat.

Pengolahan pasta tomat dimulai dengan pencucian hingga proses canning, dimana prinsip pembuatannya adalah menghilangkan sebagian kadar air dalam pasta buah sehingga membentuk suspensi yang terkonsentrat. Umumnya dalam pembuatan konsentrat buah menggunakan single atau multistage evaporation. Pada proses evaporasi, rasa dan warna jus buah dapat berubah karena adanya proses pemanasan, seperti pada jus tomat dimana terdapat degradasi senyawa lycopene, yaitu pewarna alami dalam buah yang juga dianggap sebagai agen anti kanker (Jumah dkk., 2007). Oleh karena itu, diperlukan adanya penelitian terhadap teknologi evaporasi pasta buah tomat tanpa menggunakan pemanasan, sehingga dapat mereduksi kerusakan nutrisi akibat pemberian panas.

Electroosmosis dewatering (EOD) merupakan metode dalam pengurangan kadar air dengan menempatkan suspensi koloid diantara dua elektroda. Mekanisme dewatering dengan elektroosmosis cukup berbeda dari mekanisme dewatering yang telah digunakan secara konvensional. Dewatering elektroosmosis memiliki beberapa keunggulan dibandingkan dengan dewatering mekanis dan sangat efektif untuk lumpur yang hampir tidak dapat dikeringkan seperti Partikel yang sangat halus dan bahan gelatin (Yoshida, 2007). Pengeringan elektroosmosis merupakan pengeringan yang dilakukan dengan menerapkan medan listrik eksternal dalam kondisi arus searah (DC) pada bahan semi-padat yang ditempatkan di antara dua elektroda (Nair, dkk., 2013). Metode ini menjadi hal yang menarik untuk memekatkan suspensi pasta buah yang peka terhadap panas. Pengurangan 
kadar air dengan metode elektroosmosis didasarkan pada arus listrik DC yang akan mengikat air dan membawanya bergerak mengikuti arah aliran listrik dari elektroda positif (anoda) menuju elektroda negatif (katoda). Fenomena inilah yang dapat menyebabkan air pada koloid atau suspensi mengalir sehingga dapat dimanfaatkan untuk mengurangi kadar air pada pasta buah. Zhou dkk. (2001) juga telah meneliti efek dari tegangan yang diberikan pada EOD sampel lumpur aktif. Persentase tertinggi air yang dapat dihilangkan mencapai $60 \%$ pada tegangan $80 \mathrm{~V}$ dan persentase terendah sebesar $40 \%$ pada tegangan $20 \mathrm{~V}$.

\section{Tujuan}

Berdasarkan fenomena tersebut, maka diperlukan penelitian untuk mengetahui pengaruh elektroosmosis terhadap pengurangan kadar air pada pasta buah tomat dengan variasi tegangan DC selama 100 menit. Parameter yang diukur meliputi perubahan arus DC selama proses dewatering dan kadar air pasta buah tomat.

\section{METODE PENELITIAN}

\section{Alat dan Bahan}

Bahan-bahan yang digunakan antara lain trafo stepdown $1 \mathrm{~A}$, diode, rangkaian variabel tegangan, kabel, elektroda stainless steel, akrilik, kertas saring, botol plastik PET, dan pasta tomat.

Alat-alat yang digunakan antara lain timbangan analitik, oven Metler U30, cawan alumunium foil, blender NGYT10GN, dan pisau.

\section{Metode}

$\underline{\text { Skematik Proses }}$

Skema proses elektroosmosis sebagai metode dewatering pasta buah tomat yang akan digunakan dalam penelitian ini tampak pada Gambar 1. Gambar 1 menunjukkan skema proses elektroosmosis yang akan diterapkan pada pasta buah tomat. Arus listrik yang diterapkan pada sistem adalah Direct Current (DC) dengan tegangan yang dapat divariasikan. Kutub positif elektroda bertindak sebagai anoda dan kutub negatif bertindak sebagai katoda. Elektroda positif dan negatif yang digunakan terbuat dari stainless steel, dimana sifat dari elektroda ini yang tidak mudah terkorosi namun dapat menghantarkan listrik dengan baik.

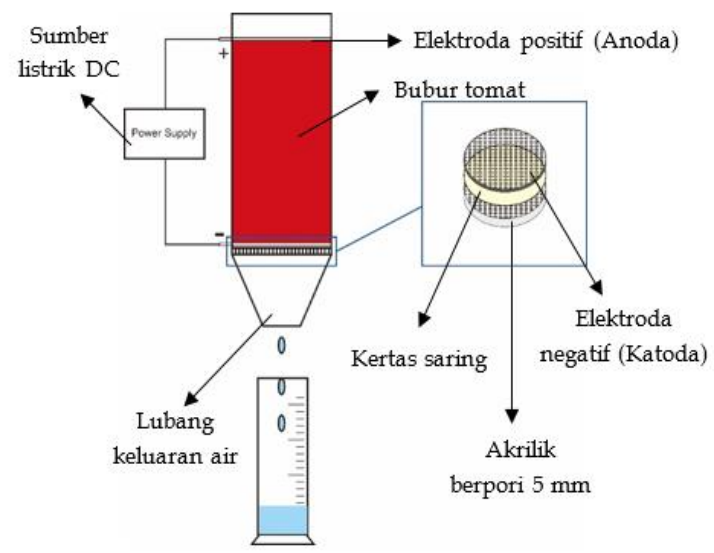

Gambar 1. Skematik Proses Electroosmosis Dewatering

Ukuran elektroda anoda dan katoda yaitu berdiameter $8 \mathrm{~cm}$, tebal $1 \mathrm{~mm}$, dengan pori-pori berdiamter $5 \mathrm{~mm}$. Poripori pada elektroda positif (anoda) dibuat berlubang dikarenakan, adanya penerapan medan listrik pada pasta buah menyebabkan terjadinya elektrolisis pada air, sehingga memicu timbulnya gas. Adanya pori-pori dapat mengeluarkan gas dari pasta buah ke atmosfir (Jumah, dkk., 2007). Elektroda positif dan negatif yang dilapisi kertas saring diletakkan pada permukaan atas dan bawah pasta tomat sehingga dapat berkontak langsung dengan pasta. Pada elektroda negatif (katoda), di bagian permukaan bawah elektroda diberikan kertas saring 1 lembar, agar pasta tomat tidak tumpah pada bagian bawah sistem elektroosmosis. Lalu di bagian bawah kertas saring, terdapat akrilik berpori dengan tebal $5 \mathrm{~mm}$ sebagai penyangga elektroda, kertas saring dan pasta buah. Pori akrilik ini juga berfungsi 
agar air hasil elektroosmosis mudah keluar dari sistem elektroosmosis.

\section{Rancangan Penelitian}

Proses pengurangan air menggunakan metode elektoosmosis pada penelitian ini dilakukan pada sampel pasta tomat dengan massa 390 gram/perlakuan. Pasta tomat dibuat dengan menghaluskan (memblender) buah tomat yang diperoleh dari pasar lokal di kota Malang. Variasi tegangan yang digunakan adalah $0 \mathrm{~V}, 4,5$ $\mathrm{V}, 9 \mathrm{~V}, 18 \mathrm{~V}$ dan $36 \mathrm{~V}$ dengan waktu proses 100 menit. Pada penelitian ini, parameter yang diukur adalah perubahan arus listrik pada sistem elektroosmosis dewatering dan perubahan kadar air awal dan akhir pada proses elektroosmosis dewatering.

\section{a. Pengujian Arus DC}

Perubahan arus listrik DC yang diterapkan pada sistem electroosmosis dewatering diukur pada 6 titik interval selama proses dewatering, yaitu setiap 20 menit selama 100 menit pengujian. Titik pengukuran, yaitu pada menit ke 0 , menit ke 20, menit ke 40, menit ke 60, menit ke 80 dan menit ke 100. Pengukuran ini dilakukan untuk melihat perubahan arus listrik yang mengalir terhadap lama proses EOD. Pengukuran dilakukan menggunakan alat ukur multimeter digital. Pengujian arus DC pada sistem elektroosmosis dilakukan penyambungan elektroda dengan adaptor DC. Setelah elektroda terhubung, langkah selanjutnya adalah mengatur multimeter pada skala miliampere arus DC, lalu multimeter positif disambungkan pada elektroda positif (anoda) dan multimeter negatif disambungkan dengan elektroda negatif. Pengujian ini dilakukan pengulangan sebanyak 3 kali.

\section{b. Pengukuran Kadar Air Pasta Tomat}

Kadar air pasta buah yang telah diberikan perlakuan elektroosmosis diuji menggunakan metode gravimetri.
Pengujian ini dilakukan untuk mengetahui kadar air sampel dari masing-masing variasi tegangan elektroosmosis yang diterapkan. Pengujian kadar air dilakukan di Laboratorium Teknik Pengolahan Pangan dan Hasil Pertanian Fakultas Teknologi Pertanian Universitas Brawijaya. Prinsip dari metode gravimetri adalah pengukuran kadar air berdasarkan penguapan air yang ada dalam bahan dengan jalan pemanasan, kemudian ditimbang sampai berat konstan. Pengurangan bobot yang terjadi merupakan kandungan air yang terdapat dalam bahan. Sampel pasta tomat yang telah diberikan perlakuan variasi tegangan diuji kadar airnya sebelum dan sesudah proses elektroosmosis. Pengulangan pengujian kadar air dilakukan 3x. Kadar air basis basah pada bahan dihitung menggunakan persamaan 1 .

Kadar air $(\%)=\frac{W 1-w 2}{w 1-w 0} \times 100 \%$

Keterangan:

W0 = Massa cawan kosong (gram)

$\mathrm{W} 1$ = Massa cawan + sampel awal (sebelum pemanasan oven)

W2 = Massa cawan + sampel awal (setelah pendinginan dalam desikator)

\section{HASIL DAN PEMBAHASAN}

\section{Sistem Electroosmosis Dewatering Pasta Tomat}

Electroosmosis Dewatering (EOD) merupakan salah satu metode penghilangan air dalam bahan dengan menerapkan aliran listrik DC pada bahan berpori. Pembuatan sistem EOD membutuhkan power supply sebagai sumber listrik DC. Komponen utama untuk membuat power supply dalam sistem EOD yaitu trafo stepdown, diode, kapasitor, rangkaian variabel tegangan, kapasitor filter, kabel, dan elektroda stainless steel. Komponen tersebut dirangkai sedemikian sehingga dapat menjadi power supply DC yang dapat 
menghasilkan tegangan output 4 level sebesar 4,5 V, 9 V, 18 V, dan 36 V. Fungsi masing-masing komponen tersebut yaitu, trafo stepdown berfungsi sebagai trafo untuk menurunkan tegangan listrik menjadi tegangan yang diinginkan, dimana tegangan maksimal yang dapat dicapai trafo ini adalah $36 \mathrm{~V}$. Dioda berfungsi sebagai penyearah listrik AC menjadi DC, kapasitor berfungsi untuk menyempurnakan penyearahan dari tegangan AC ke DC, sehingga kapasitor ini dapat meredam dengung dari tegangan AC. Rangkaian variabel tegangan berfungsi untuk mengatur tegangan output yang diinginkan, dalam alat ini terdapat 4 rangkaian variabel tegangan karena tegangan output yang dibutuhkan terdapat 4 level tegangan output yang dihasilkan dari rangkaian variabel tegangan akan ditampilkan pada voltmeter digital pada kontrol box. Berikut merupakan Gambar 2 Rangkaian listrik sistem Electroosmosis Dewatering.

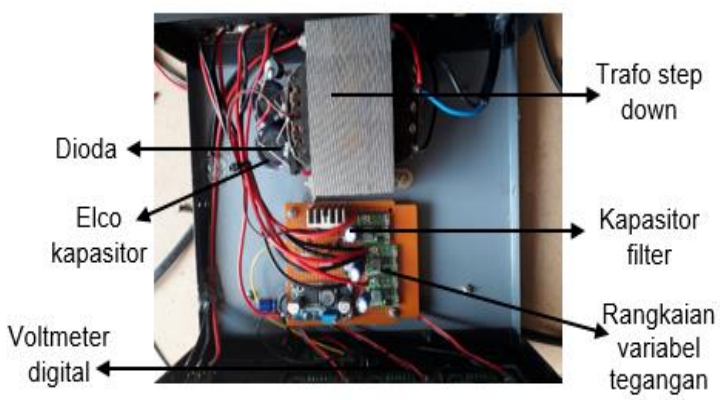

Gambar 2. Rangkaian Listrik Sistem Electroosmosis Dewatering

Proses elektroosmosis pasta tomat dilakukan pada wadah botol plastik PET ukuran 1 liter. Botol plastik dipilih karena harganya murah dan mudah untuk dipotong dan disesuaikan dengan skema proses EOD. Botol plastik ini dimodifikasi agar terintegrasi dengan rangkaian listrik yang menghasilkan 5 variasi tegangan DC yaitu $0 \mathrm{~V}, 4,5 \mathrm{~V}, 9 \mathrm{~V}, 18 \mathrm{~V}$, dan $36 \mathrm{~V}$ yang tampak seperti pada Gambar 3 berikut

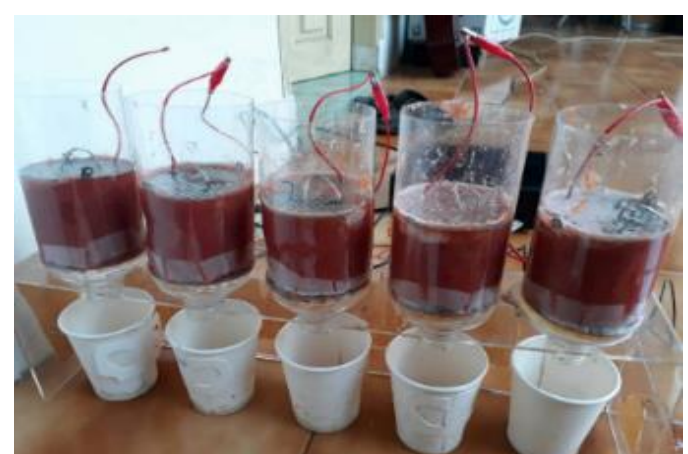

Gambar 3. Wadah Proses Electroosmosis Dewatering

Pengaruh Proses Electroosmosis Dewatering (EOD) Terhadap Arus Listrik

Electroosmosis Dewatering (EOD) yang diterapkan pada proses dewatering pasta tomat menggunakan arus dan tegangan listrik DC. Selama proses berlangsung (100 menit) arus listrik yang mengalir disetiap tegangan diukur setiap 20 menit. Adapun perubahan arus listrik tersebut tampak seperti Gambar 4.

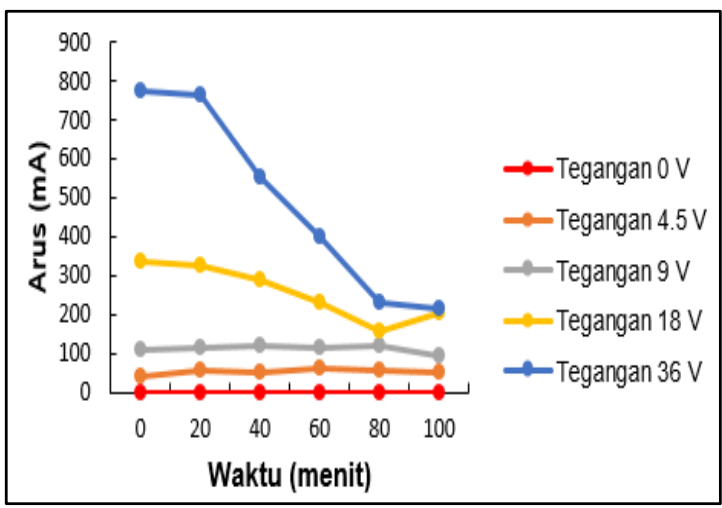

Gambar 4. Grafik Perubahan Arus Terhadap Lama Proses Electroosmosis Dewatering

Gambar 4 menunjukkan bahwa semakin tinggi tegangan yang diberikan maka arus listrik juga semakin tinggi. Hal ini sesuai dengan penelitian yang dilakukan oleh Sariningpuri (2012) tentang pengaruh elektroosmosis pada sludge. Penelitian tersebut mengungkapkan bahwa perubahan arus tergantung dari besarnya tegangan (voltase) yang diberikan pada sludge. Semakin tinggi tegangan yang diberikan maka arus yang mengalir selama 
elektroosmosis juga menjadi semakin tinggi. Gambar 4 juga menunjukkan bahwa semakin lama waktu proses terdapat penurunan arus DC secara drastis pada tegangan $18 \mathrm{~V}$ dan $36 \mathrm{~V}$, sedangkan pada tegangan 4,5 $\mathrm{V}$ dan $9 \mathrm{~V}$ tampak lebih stabil. Terdapat beberapa hal yang dapat menyebabkan terjadinya penurunan arus DC yaitu, turunnya kandungan air dalam bahan (pasta tomat), dimana volume air dalam bahan mengalami penurunan karena adanya sistem electroosmosis dewatering. Air yang terdapat pada pasta tomat memiliki $\mathrm{pH}$ rendah atau bersifat asam sehingga mudah mengalirkan arus listrik. Menurut Koneman (2006) pH pasta tomat yaitu 4,35 $\pm 0,01$ dan pada penelitian ini nilai rata-rata $\mathrm{pH}$ air dari pasta tomat tanpa pemberian tegangan atau tegangan $0 \mathrm{~V}$ adalah 4,867, sehingga $\mathrm{pH}$ pasta tomat termasuk asam. Menurut Asmarani (2017) suatu larutan asam dapat menghantarkan elektron dan menghasilkan arus listrik. Berdasarkan hal tersebut, maka berkurangnya volume air dalam pasta tomat juga dapat menurunkan arus listrik yang mengalir selama proses. Penurunan drastis terlihat pada tegangan $18 \mathrm{~V}$ dan $36 \mathrm{~V}$ dimana volume air pada pasta berkurang banyak pada tegangan tersebut, sedangkan pada tegangan $4,5 \mathrm{~V}$ dan $9 \mathrm{~V}$ air yang dikeluarkan dari sistem tidak secepat dan sebanyak tegangan $18 \mathrm{~V}$ dan $36 \mathrm{~V}$.

Selain volume air, proses electroosmosis dewatering juga menimbulkan gelembung gas sesuai reaksi elektrolisis pada gambar 5 .

$$
\begin{aligned}
& 2\left(2 \mathrm{H}_{2} \mathrm{O}+2 e^{-} \longrightarrow \mathrm{H}_{2}+2 \mathrm{OH}^{-}\right) \quad \text { (reduction, athode) } \\
& 2 \mathrm{H}_{2} \mathrm{O} \longrightarrow \mathrm{O}_{2}+4 \mathrm{H}^{+}+4 e^{-} \\
& 6 \mathrm{H}_{2} \mathrm{O} \longrightarrow 2 \mathrm{H}_{2}+\mathrm{O}_{2}+\underbrace{4 \mathrm{H}^{+}+40 \mathrm{H}^{-}}_{4 \mathrm{H}_{2} \mathrm{O}} \text { (overall cell reaction) } \\
& 2 \mathrm{H}_{2} \mathrm{O} \longrightarrow 2 \mathrm{H}_{2}+\mathrm{O}_{2} \quad \text { (net reaction) }
\end{aligned}
$$

Gambar 5. Reaksi Elektrolisis yang Terjadi Pada Proses Elektroosmosis
Pada Gambar 5 reaksi elektrolisis yang terjadi pada saat elektroosmosis menghasilkan net reaction berupa gas oksigen dan hidrogen. Menurut Asheh dkk. (2004) saat proses dewatering berlangsung, electric field menghasilkan pembentukan gas yang signifikan dan menyebabkan resistansi meningkat dengan cepat.

\section{Kadar Air Pasta Tomat dengan Adanya Sistem Electroosmosis Dewatering (EOD)}

Kadar air pasta tomat diukur dengan standar (SNI 01-2891-1992), dimana kadar air sebelum proses dan setelah proses diukur. Pemberian sistem electroosmosis dewatering selama waktu proses 100 menit dengan masing-masing tegangan yaitu $0 \mathrm{~V} ; 4,5 \mathrm{~V} ; 9 \mathrm{~V} ; 18 \mathrm{~V}$; dan $36 \mathrm{~V}$ memberikan pengaruh terhadap kadar air pasta. Semakin besar tegangan yang diterapkan, maka kadar air pasta tomat semakin rendah seperti tampak pada gambar 6. Kadar air awal (sebelum perlakuan elektroosmosis) pasta tomat yaitu 94,97\%. Setelah 100 menit proses filtrasi tanpa pemberian tegangan $(0 \mathrm{~V})$ kadar air pasta menurun menjadi $94,11 \%$, dan semakin menurun dengan meningkatnya tegangan yang diberikan pada sistem, dimana berturut turut perubahan kadar air berdasarkan pemberian tegangan $4,5 \mathrm{~V} ; 9 \mathrm{~V} ; 18 \mathrm{~V}$; dan $36 \mathrm{~V}$, yaitu 93,81\%; 93,79; 92,70\%; dan $92,28 \%$. Penurunan kadar air pada pasta tomat ini dikarenakan air pada sistem juga semakin berkurang dengan semakin meningkatnya tegangan yang diberikan. Hal tersebut membuktikan bahwa adanya pemberian medan listrik DC pada pasta tomat menyebabkan kandungan air pada pasta tomat akan mengalir mendekati area elektroda negatif yang terletak pada bagian bawah sistem EOD sehingga menetes keluar dari sistem EOD sesuai dengan prinsip elektroosmosis. 


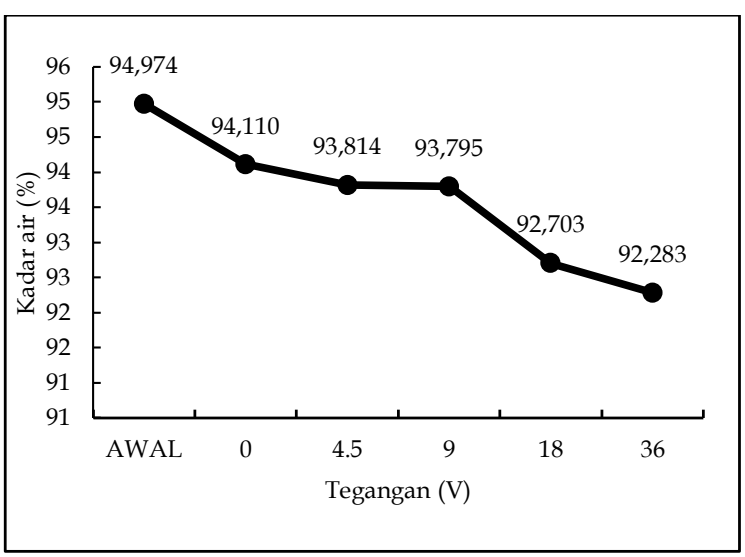

Gambar 6. Grafik Pengaruh Tegangan

Terhadap Kadar Air Pasta Tomat

Menurut Najundaswamy (2015) medan listrik pada elektroosmosis menyebabkan terjadinya pergerakan air yang terdapat pada media berpori. Transport elektroosmosis air melalui media adalah hasil dari kation lapisan ganda yang tersebar pada pori-pori media yang kemudian tertarik menuju katoda (elektroda negatif). Ketika kation ini bergerak menuju katoda (elektroda negatif), maka molekul air yang menggumpal disekitar kation akan terbawa menuju katode (elektroda negatif) sebagai konsekuensi dari sifat dipolar air. Agustino dalam Pidin (2013) juga menyatakan bahwa semakin besar tegangan yang digunakan pada elektroosmosis akan semakin cepat terjadi penurunan yang terjadi dan semakin dekat jarak antara anoda dan katoda, maka semakin cepat pula penurunan yang terjadi karena air yang keluar pun semakin meningkat.

Nilai standar kadar air pada pasta tomat impor yaitu $77 \%$ untuk merk Heinz, 78,2\% untuk merk Del Monte, dan 78,3\% untuk merk S\&W (Bella, 2002). Berdasarkan standar tersebut, maka proses dewatering menggunakan elektroosmosis selama 100 menit dengan massa proses 390 gram pasta tersebut belum mampu menghasilkan pasta tomat dengan kadar air yang sesuai standar. Untuk mendapatkan kadar air pasta yang rendah, langkah yang dapat dilakukan adalah memperlama proses elektroosmosis. Berikut merupakan kenampakan pasta tomat setelah proses electroosmosis dewatering selama 100 menit.

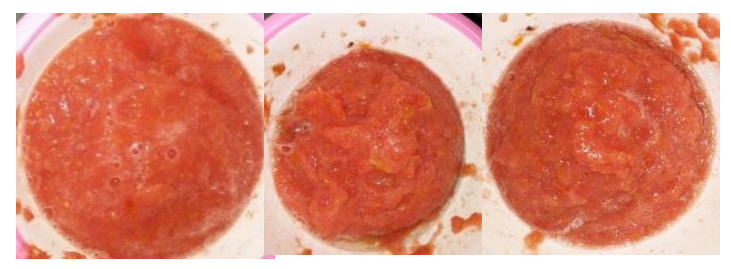

(a)

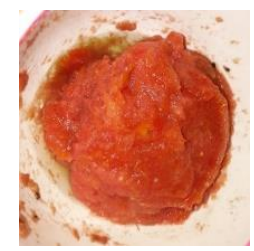

(d) (b)

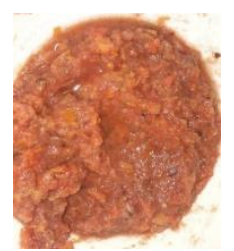

(e)
Gambar 7. Kenampakan Pasta Tomat Setelah Proses Electroosmosis Dewatering

(a) tegangan $0 \mathrm{~V}$; (b) tegangan $4,5 \mathrm{~V}$; (c) tegangan $9 \mathrm{~V}$; (d) tegangan $18 \mathrm{~V}$; (e) tegangan $36 \mathrm{~V}$

Kenampakan pasta tomat mengalami perubahan dengan meningkatnya tegangan yang diberikan, semakin besar tegangan pasta tomat lebih kental, namun pada pemberian tegangan $36 \mathrm{~V}$ DC warna pasta tomat lebih gelap kehitaman. Dalam penelitian terdahulu yang dilakukan oleh Lighfoot (1991) tentang kombinasi elektroosmosis dan tekanan dalam pengeringan Kelp menyatakan bahwa percobaan pertamanya dalam elektroosmosis dapat menyebabkan perubahan warna pada press cake di anoda, dimana warnanya menjadi kuning kecoklatan. Selain itu, Reaksi antara senyawa organik dengan udara akan menghasilkan warna hitam atau coklat gelap. Reaksi oksidasi ini dipercepat oleh adanya logam serta enzim. Berdasarkan literatur tersebut perubahan warna pada pasta tomat dapat dikarenakan adanya oksidasi dari gas oksigen yang terbentuk pada proses elektroosmosis serta adanya 
kontak dengan logam pada elektroda stainless steel.

\section{KESIMPULAN}

Pada sampel pasta tomat dengan massa 390 gram per proses yang dialiri arus listrik DC selama 100 menit, dengan variasi tegangan $0 \mathrm{~V} ; 4,5 \mathrm{~V} ; 9 \mathrm{~V} ; 18 \mathrm{~V}$, dan $36 \mathrm{~V}$ memberikan perbedaan tingkat dewatering pada pasta tomat. Kadar air rata-rata pada pasta tomat yang diberi tegangan $36 \mathrm{~V}$ selama 100 menit adalah $92,28 \%$ sedangkan pada tegangan $0 \mathrm{~V}$ adalah $94,11 \%$. Semakin besar tegangan listrik yang diberikan, maka semakin kecil kadar air pasta tomat tersebut. Arus listrik pada tegangan $36 \mathrm{~V}$ dan $18 \mathrm{~V}$ cenderung mengalami penurunan dari arus awal dengan semakin lamanya proses, sedangkan pada tegangan $4,5 \mathrm{~V}$ dan $9 \mathrm{~V}$ cenderung lebih stabil. Semakin tinggi tegangan yang diberikan, arus listrik yang mengalir juga semakin besar.

\section{DAFTAR PUSTAKA}

Asheh, A.S., Jumah, R., Banat, F., dan Zou'bi, K.A. (2004). Direct Current Electroosmosis Dewatering of Tomato Paste Suspension. Food and Bioproducts Processing. Vol. 82(C3): 192-200.

Asmarani, Suci. (2017). Analisis Jeruk Dan Kulit Jeruk Sebagai Larutan Elektrolit Terhadap Kelistrikan Sel Va. (SKRIPSI). Jurusan Fisika: Universitas Lampung.

Bella, D.S. 2002. Pengaruh Varietas dan Evaporasi Terhadap Mutu Pasta Tomat. (SKRIPSI). Fakultas Teknologi Pertanian, Institut Pertanian Bogor.

BPS. (2017). Konsumsi Buah Dan Sayur Susenas Maret 2016. Jakarta, Badan Pusat Statistik.

Jumah, R., Asheh, S.A., Banat, F., dan K A Zoubi. (2007). Influence of Salt, Starch and $\mathrm{pH}$ on the Electroosmosis
Dewatering of Tomato Paste Suspension. Journal of Food, Agriculture \& Environment. Vol. 5(1): 34-38.

Koneman, E.W. (2006). Koneman's Color Atlas and Textbook of Diagnostic Microbiology. Philadelphia:

Lippincott Williams \& Wilkins

Lighfoot, D.G. (1991). Combined Fields (Electroomosis and Pressure) Dewatering of Kelp. (THESIS). Macdonald Campus of McGill University.

Nair, G.R., Rho, D., dan Raghavan, G.S.V. (2013). Application of Electro-Technologies in Processing of Flax Fiber. FIBERS. ISSN 20796439

Najundaswamy. (2015). Construction Dewatering. Mysuru: S J College of Engineering.

Pidin, Faqihna. (2013). Pengeringan Sludge Limbah Cair Dari Tempat Pembuangan Sampah Secara Elektroosmosis Pada Skala Semi Lapang. (SKRIPSI). Departemen Ilmu Tanah Dan Sumberdaya Lahan: Institut Pertanian Bogor

Sariningpuri, Juniska Muria. (2012). Penerapan Elektroosmosis Untuk Pengeringan Sludge Air Lindi Dari Sampah dan Lumpur Endapan Pengolahan Air Minum. (SKRIPSI). Departemen Ilmu Tanah Dan Sumberdaya Lahan: Institut Pertanian Bogor.

Suhariyanto. (2018). Statistik Tanaman Sayuran dan Buah-buahan Semusim Tahun 2017. Jakarta, Badan Pusat Statistik

Yoshida, H. (2007). Practical Aspects Of Dewatering Enhanced By ElectroOsmosis. Journal of Drying Technology. Vol.11(4): 784-814

Zhou, J., Zheng, L., Peng, S., dan Fuxing, D. (2001). Water Removal From Sludge in a Horizontal Electric field. Drying Technoogy. Vol. 19: 627638. 